\title{
The Exposed Surface Area To Volume Ratio: Is Shell More Efficient Than Limestone In Promoting Oyster Recruitment?
}

KM Kuykendall

P Moreno

EN Powell

TM Soniat

S Colley

See next page for additional authors

Follow this and additional works at: https://scholarworks.wm.edu/vimsarticles

Part of the Marine Biology Commons

\section{Recommended Citation}

Kuykendall, KM; Moreno, P; Powell, EN; Soniat, TM; Colley, S; Mann, Roger L.; and Munroe, DM, "The Exposed Surface Area To Volume Ratio: Is Shell More Efficient Than Limestone In Promoting Oyster Recruitment?" (2015). VIMS Articles. 311.

https://scholarworks.wm.edu/vimsarticles/311

This Article is brought to you for free and open access by the Virginia Institute of Marine Science at W\&M ScholarWorks. It has been accepted for inclusion in VIMS Articles by an authorized administrator of W\&M ScholarWorks. For more information, please contact scholarworks@wm.edu. 
Authors

KM Kuykendall, P Moreno, EN Powell, TM Soniat, S Colley, Roger L. Mann, and DM Munroe 


\title{
THE EXPOSED SURFACE AREA TO VOLUME RATIO: IS SHELL MORE EFFICIENT THAN LIMESTONE IN PROMOTING OYSTER RECRUITMENT?
}

\author{
KELSEY M. KUYKENDALL, ${ }^{\text {* PAULA MORENO, }}{ }^{1}$ ERIC N. POWELL, ${ }^{1}$ THOMAS M. SONIAT, \\ SUSAN COLLEY, ${ }^{2}$ ROGER MANN ${ }^{3}$ AND DAPHNE M. MUNROE ${ }^{4}$ \\ ${ }^{1}$ Gulf Coast Research Laboratory, University of Southern Mississippi, 703 E. Beach Drive, Ocean Springs, \\ MS 39564; ${ }^{2}$ Department of Biological Sciences, University of New Orleans, 2000 Lakeshore Drive, New \\ Orleans, LA 70148; ${ }^{3}$ Virginia Institute of Marine Science, College of William and Mary, P.O. Box 1346, \\ Gloucester Point, VA 23062; ${ }^{4}$ Haskin Shellfish Research Laboratory, Rutgers University, 6959 Miller \\ Avenue, Port Norris, NJ 08349
}

\begin{abstract}
Planting oyster cultch is a common management approach used to enhance recruitment. The two most popular cultch materials are shell and limestone. Both are sold by volume or weight; however, once deposited on oyster grounds, only a small portion of the total surface area of each particle is available for recruitment. Shell and limestone have different surface area to volume properties, and thus provide differential settlement opportunities. Exposed surface area to volume (expSA/V) ratios of oyster shell and limestone fragments were compared, as an indicator of their recruitment potential and cost-effectiveness for cultch planting. Samples were collected from the Primary Public Oyster Seed Grounds in Louisiana by vibracore, and from the Pass Christian Tonging Grounds in Mississippi by dredge. Shell (including whole shell and fragments) and limestone particles greater than or equal to $8 \mathrm{~mm}$ by geometric shape were classified and their expSA/V was calculated. Mean expSA/V ratios of shell were approximately three to nine times higher than limestone. For limestone of similar particle size to provide an equivalent recruitment benefit for the same cost would require that the cost of purchase, transport, and planting be three to nine times lower than shell. Thus, shell is likely to be a more efficient material than limestone for recruitment enhancement. Nevertheless, the higher variability in expSA/V of shell and other factors such as the expected lifetime and the relative performance of small and large particles of materials should also be considered. Analysis of a Louisiana limestone plant and associated oyster cultch showed that the proportion of small and large limestone particles and the relative proportion of whole shells and fragments can greatly alter expSA/V. In this case, the a priori expectation that oyster shell would outperform limestone did not materialize because of the quantity of small limestone particles of favorable shapes in the deployed material. Even so, as yet unknown is the possible reduction in performance in situ of smaller particles that might occur if they increase the one-dimensionality of the plant.
\end{abstract}

KEY WORDS: oyster, shell planting, limestone, cultch, restoration, recruitment, surface area

\section{INTRODUCTION}

The eastern oyster Crassostrea virginica (Gmelin, 1791) is an important contributor to ecosystem services in estuaries by providing important topographic relief and habitat complexity in the form of oyster reefs that support a diversity of estuarine life (Gunter 1979, Peterson et al. 2003, Coen et al. 2007). Oyster reefs offer many other benefits and services to their surrounding environments, both aquatic and human inhabited (Hedgpeth 1953, Gunter 1979, Kingsley-Smith et al. 2012), not the least of which is support for important estuarine fisheries (Mann et al. 1991, Mackenzie 1996, Powell et al. 2008, Vanderkooy 2011). The oyster industry not only provides a commercially important food source, but also is an important source of jobs and economic benefit to coastal harvesting areas (Wirth \& Minton 2004, Lipton 2008, Santopietro et al. 2009). Nevertheless, these keystone organisms that are responsible for nutrient cycling, biofiltration, biodiversity, habitat structure, and economic benefit are currently in decline worldwide (Beck et al. 2009), including the U.S. East and Gulf coasts (Mann et al. 1991, Hargis \& Haven 1994, Mackenzie 2007, Soniat et al. 2012) due to stressors such as habitat destruction during harvest (Lenihan \& Peterson 1998, Woods et al. 2005), overharvesting (Rothschild

*Corresponding author. E-mail: kelsey.kuykendall@usm.edu DOI: $10.2983 / 035.034 .0203$ et al. 1994, Jordan \& Coakley 2004), and disease (Powell et al. 2009, Powell et al. 2012).

Much effort has been invested in the restoration of oyster beds through habitat creation (Breitburg et al. 2000, Mann \& Powell 2007, Gregalis et al. 2008, Powers et al. 2009) and the enhancement of abundance through habitat revitalization (Abbe 1988, Harding et al. 2010, Southworth et al. 2010) to rebuild a once thriving natural resource. A recent restoration project local to the sampling areas of this study took place from Fall 2012 to Spring 2013. As part of a negotiated US\$1 billion restoration "down payment" in response to the Deep Water Horizon oil spill (Sammarco et al. 2013), US\$11 million was dedicated to depositing limestone over a total of 1,430 acres of oyster beds. A minimum of US\$100 million has been promised to the state of Mississippi (MDEQ 2013).

A range of materials has been tested and used to build oyster reefs or enhance recruitment through the provision of additional substrate. Such cultch materials include man-made materials such as concrete (Butler 1955, Haven et al. 1987, Soniat et al. 1991, Soniat \& Burton 2005, Toline et al. 2005) and other biological sources such as bivalve shell other than oysters. Surf clam (Spisula solidissima) shell was compared with oyster shell in the Chesapeake Bay, and found to be associated with higher juvenile mortality rates and less structural complexity (Nestlerode et al. 2007); both surf clam and ocean quahog shell, however, were routinely used in the Delaware Bay with success (e.g., 
HSRL 2011). Nevertheless, limestone and oyster shell are the typical materials selected for recruitment enhancement and reef creation (Churchill 1920, Lunz 1957, Gunter 1972, Anonymous 2004, Bushek et al. 2004, Soniat \& Burton 2005, Gregalis et al. 2009, Powers et al. 2009). Oyster shell is commonly recycled from shucking operations back to the local estuary, particularly in cases where leases permit private control of the planted shell (Agnello \& Donnelley 1975, Mackenzie 1996). Nevertheless, limestone is increasingly used rather than shell owing to its availability, cost, and ability to attract spat (Anonymous 2004, Soniat \& Burton 2005).

Placing clean substrate into the water at spawning time is a time-honored mechanism to produce settlement rates of spat consistently superior to substrate already on the bottom (Churchill 1920, Abbe 1988, Kennedy et al. 2011). Mudshell, that is buried oyster shell, shell cured on land for a period, and alternate substrates such as limestone, are more advantageous presumably because either the organic coating has been destroyed by bacterial action or drying and the surfaces are free of the typical slime associated with fouling organic matter (Gunter 1979, Bushek et al. 2004) or, in the case of limestone, the surface is inherently clean. Although a number of studies have addressed settlement cues for oyster larvae (Ritchie \& Menzel 1969, Hidu et al. 1978, Weiner et al. 1985, Fitt \& Coon 1992), why "clean" substrate improves recruitment remains a mystery.

After the deposition of cultch material, only a portion of the total surface area intended for spat recruitment remains exposed. This portion varies between materials used, deployment procedures, and bottom consistency. Despite the substantial investment in shell planting that has occurred throughout the eastern oyster's range over many years, few studies have addressed the question of optimization of planting protocol to achieve a desired level of success in either enhancing recruitment, establishing bottom consistency, or creating vertical relief. Limestone tends to form a monolayer; whereas, oyster shell offers increased vertical complexity because of a lessened ability for the concave shell to pack into a semicontinuous stratum (Powers et al. 2009). Vertical complexity (clumpiness) and vertical relief (height above the surrounding bottom) are important characteristics of a growing and sustainable oyster reef (Lenihan 1999, Grabowski \& Powers 2004, Powell et al. 2012) with reports of four times higher oyster densities on reefs with high vertical relief than found on low profile reefs (Nestlerode et al. 2007). Thus, the differential performance of cultch materials in large measure may be determined by deployment protocol and the balance between availability, cost efficiency, and degree of recruitment enhancement as determined in large measure by exposed surface area after planting. The objective of this project is to focus on the relationship between surface area that influences performance, and volume that influences price. For this purpose, the efficiency of two common cultch materials with respect to both biological and economic efficiency by means of simulations and statistical analysis is compared.

\section{MATERIALS AND METHODS}

\section{Approach and Materials Source}

Shell and limestone are usually purchased and planted by volume. Because of the variation in the definition of the bushel between states (e.g., Hopkins 1950, Owen 1953, DeAlteris 1988, Powell et al. 2008, Vanderkooy 2011), analysis focused on a more consistently used unit of measure, the cubic yard $\left(1 \mathrm{yd}^{3}=0.7646 \mathrm{~m}^{3}\right)$. Weight is potentially an important metric if planting costs include a shipping fee to reach the deposition location. Thus, comparisons were made by weight and by volume. Planting costs include all expenses for purchase, transport, and deposition of the material.

A Monte Carlo program was used to simulate cubic yards of a selected material to create samples for statistical analysis. Sample sources included both industrial and field origin. Representative samples of two sizes of limestone and oyster shell were obtained from an industrial provider. These samples were used for the estimation of the void volume associated with particles of different type, shape, and size. Field data sets came from a limestone planted area, Three Mile Bay, in the Primary Public Oyster Seed Grounds in Louisiana (Soniat et al. 2014) and were collected by vibracore and hydraulic patent tong. Additional samples were collected from the Pass Christian Tonging Grounds in Mississippi by dredge. Sampling gear was determined by the availability at the sites.

\section{Determination of Particle Total Surface Area and Exposed Surface Area}

Vibracore samples from Three Mile Bay illuminated some characteristics of deposited cultch material (Fig. 1). Other field sources included dredge and hydraulic patent tong samples from oyster grounds off the coasts of Pass Christian, MS, and from Black Bay and Bay Gardene, LA. Examination of the upper portion of the sediment cores showed that limestone forms a compacted, continuous, and relatively flat surface layer when deposited in sufficient quantity (Fig. 1). In comparison with limestone, shell, because of its concave shape, offers a more complex matrix of shell and void space.

To calculate the total surface area of an object, a shape type was assigned to the particle based on criteria set to define the shape and appropriate measurements were taken by calipers to enable use of simple geometric formulae. Shape categories for limestone included cube, triangular prism, and square-based and triangular-based pyramids as shown in Figure 2. Shell was divided between whole shells and fragments. The formula for whole shell surface area includes a correction factor $(0.8)$ to account for the ovoid shape (Fig. 2). Shell fragments were categorized as either subquadrilateral or subtriangular (Fig. 2). The surface area of one face of the shell was doubled to obtain total surface area owing to the inability to consistently measure a standard thickness for shell pieces and the minimal additional surface area contributed by shell edges.

To obtain a value for the expSA of a particle, it is assumed that exposed surface area would approximate the surface area of one face of the particle. This is likely the case at high planting densities as observed in Figure 1. Thus, the total surface area was divided by the number of faces of the particle. This allowed for an average expSA regardless of what face of the object actually was exposed. A related assumption was that burial is unimportant beyond the close packing that occurs during planting. It is assumed that only one exposed face of the shell creates a negative bias of the expSA estimate because it is likely, owing to the natural shape of the shell, that some portion of both sides is exposed. The same bias exists for limestone, but to a much lesser degree. It is also assumed that no sedimentation or 

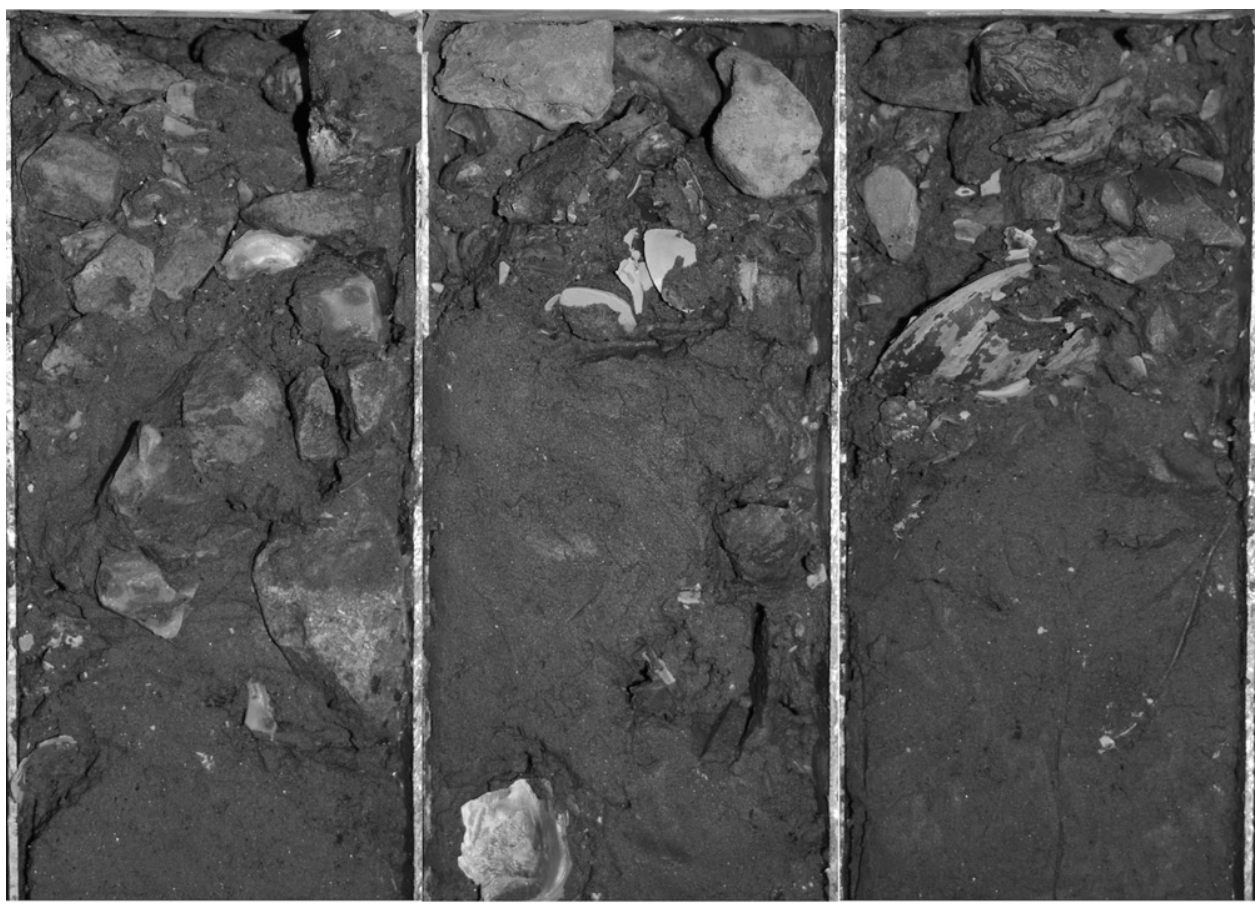

Figure 1. Representative vibracore samples from Three Mile Bay, LA, displaying the ability of limestone to compact into a relatively flat continuous surface layer of particles.

burial creates a positive bias for the expSA of limestone because the compactness of limestone plants makes them more susceptible to a recruitment-preventing dusting of sediment. Even a fine dusting of sediment will restrict epibiont attachment (Parsons-Hubbard et al. 1999), including attachment of oyster spat. Thus, the comparisons are idealized relative to the vagaries imposed by planting density and bottom consistency that can be expected to exert an important local effect on realized exposed surface area.

\section{Estimation of Void Volume}

Volume measures of crushed limestone and oyster shell include not only the volume of the material itself, but also the void volume, as these particles do not pack tightly together. Conversion factors were developed to permit inclusion of void volume in bulk volume measures using the ratio of (particle volume + void volume) / particle volume (Table 1). For a range of particle types, these ratios varied from 1.9 to 3.3 for the various limestone shapes. The ratio for whole market-size oyster shells was 5.4. Limestone packs together such that the void volume is half or less than that of oyster shell, for most particle shapes. Oyster shell fragments, on the other hand, had a very low ratio; that is, a bulk volume of shell fragments had much less void volume than the other material types.

\section{Sample Generation Using the Monte Carlo Program}

A Monte Carlo program was used to produce 1,000 onecubic-yard samples with characteristics similar to cubic yards of material that are purchased for routine cultch planting and restoration efforts. Each simulated cubic yard was created by random selection (with replacement) of individual particles from one of the industrial datasets or field datasets. Each particle brought with it the appropriate void volume. Particles continued to be drawn until the total of the particle and void volumes reached $1 \mathrm{cu}$ yd. Running totals of total surface area, expSA, volume, and weight were kept for analysis. Crushed

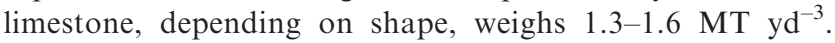
Weights obtained for a simulated cubic yard of limestone consistently fell within this range, indicating that the volume to weight conversions used, including the void volumes associated with particle shape and size, produced a similar composition to the material used for restoration efforts.

\section{RESULTS}

\section{Analyses of Simulated Cultch Materials}

The mean surface area-to-volume ratio for market-size oyster shell was $4.1 \mathrm{~cm}^{2} \mathrm{~cm}^{-3}$ with $50 \%$ of the measurements falling between 3.2 and $4.8 \mathrm{~cm}^{2} \mathrm{~cm}^{-3}$. The surface area-tovolume ratio for limestone varied by particle shape. Four-sided and five-sided particles had lower surface-to-volume ratios than whole oyster shell (four-sided: $3.3 \mathrm{~cm}^{2} \mathrm{~cm}^{-3}$; central $50 \%, 2.1-4.0 \mathrm{~cm}^{2} \mathrm{~cm}^{-3}$; five-sided: $3.2 \mathrm{~cm}^{2} \mathrm{~cm}^{-3}$; central $50 \%$, $2.2-3.8 \mathrm{~cm}^{2} \mathrm{~cm}^{-3}$ ). Six-sided particles, however, had a higher surface area-to-volume ratio than whole oyster shell at $6.0 \mathrm{~cm}^{2} \mathrm{~cm}^{-3}$ (central 50\%, 4.1-6.9 $\mathrm{cm}^{2} \mathrm{~cm}^{-3}$ ).

Particle surface area, not surprisingly, was significantly related to particle volume (analysis of variance [ANOVA]: $P<0.0001)$. The main effect, particle type, was also significant $(P<0.0001)$, as was the interaction term $(P<0.001)$, indicating that surface area scaled differently with particle volume for the different particle types. An a posteriori least-square means test showed that all primary particle types (shell and the four limestone shapes: cube, square-base pyramid, triangular-base pyramid, triangular prism) differed significantly in surface area 


\begin{tabular}{|c|c|c|}
\hline Shape & Classification Criteria & Total Surface Area \\
\hline Cube & $\begin{array}{l}\text { four definite edges on } \\
\text { each face of } \\
\text { approximately equal } \\
\text { length }\end{array}$ & $\begin{aligned}= & 2\left(\text { Width }{ }^{*} \text { Height }+\right. \\
& \text { Length }{ }^{*} \text { Width }+ \\
& \left.\text { Length }{ }^{*} \text { Height }\right)\end{aligned}$ \\
\hline $\begin{array}{l}\text { Triangular } \\
\text { Prism }\end{array}$ & $\begin{array}{l}\text { two opposing triangular } \\
\text { faces with a ridge } \\
\text { connecting the points of } \\
\text { the opposing triangular } \\
\text { faces that are } \\
\text { approximately the same } \\
\text { length }\end{array}$ & $\begin{array}{c}=\text { Base }{ }^{*} \text { Height }+ \\
2\left(\text { Length }{ }^{*} \text { Slant }\right)+ \\
\text { Length }{ }^{*} \text { Base }\end{array}$ \\
\hline $\begin{array}{l}\text { Square-based } \\
\text { Pyramid }\end{array}$ & $\begin{array}{l}\text { four triangular shaped } \\
\text { faces that share a square } \\
\text { base }\end{array}$ & $\begin{array}{c}=2\left(\text { Base }^{*} \text { Slant }\right)+ \\
\text { Base }^{2}\end{array}$ \\
\hline $\begin{array}{l}\text { Triangular- } \\
\text { based } \\
\text { Pyramid }\end{array}$ & $\begin{array}{l}\text { four faces that are all } \\
\text { triangular in shape }\end{array}$ & $\begin{array}{c}=\left(0.5^{*} \text { Apothem } *\right. \\
\text { Height })+\left(3 / 2{ }^{*} \text { Height }\right. \\
\text { Slant })\end{array}$ \\
\hline Whole Shell & whole or nearly whole & $=2\left(\right.$ Length ${ }^{*}$ Width $)(0.8)$ \\
\hline $\begin{array}{l}\text { Subquadrilater } \\
\text { al Shell }\end{array}$ & $\begin{array}{l}\text { pieces with four definite } \\
\text { edges }\end{array}$ & $=2\left(\right.$ Length ${ }^{*}$ Width $)$ \\
\hline $\begin{array}{l}\text { Subtriangular } \\
\text { Shell }\end{array}$ & $\begin{array}{c}\text { pieces with three definite } \\
\text { edges }\end{array}$ & $=$ Base $^{*}$ Height \\
\hline
\end{tabular}

Figure 2. Outline of the shape categories, criteria, and total surface area formulae for classification of limestone and shell particles. The top four cells are limestone categories and the bottom three cells are shell categories. Both size classes of limestone were divided into the same shape categories.

from each other with the exception of the square-base pyramidal and triangular-base pyramidal shapes, which were not significantly different from each other. Surface area rose more rapidly for some particle shapes than others, with pyramidal shapes lagging and square shapes leading (Table 2), hence, the significant interaction term. Oyster shell fell in between.

The performance of a cubic yard of material can be evaluated as the amount of exposed surface area (in $\mathrm{m}^{2}$ ) per cubic yard of material planted. Exposed surface area was estimated as the area of one face of each particle type. Exposed surface area was significantly related to particle volume (ANOVA: $P<0.0001$ ). The main effect, particle type, was also significant $(P<0.0001)$, as was the interaction term $(P<0.001)$, indicating that exposed surface area scaled differently with particle volume for different particle types. An a posteriori least-square means test showed that shell differed significantly from all of the limestone particle shapes. Cubic limestone and limestone triangular prisms, although not being significantly different among themselves, differed significantly from all other limestone shapes in presenting more exposed surface area as a function of volume. Pyramidal shapes provided the least surface area per volume of the limestone particle shapes (Table 3).

The resulting metrics of simulated cubic yards of material suggest that although limestone provides more total surface area, shell provides the most exposed surface area, with prismatic limestone particles nearly equaling oyster shell in this most important metric. Smaller limestone particles have slightly less void volume associated with each particle than larger limestone particles, whereas the pyramidal shapes have more void volume per cubic yard than the other shapes. Accordingly, the smaller size class outperformed the larger category in both total and exposed surface area per cubic yard. Pyramidal shapes, even bound together, provided least amount of both total and exposed surface area.

A cubic yard of limestone weighs considerably more than the same bulk volume of market-size oyster shell (Table 3). Although the density of the materials differs somewhat, most of this differential is contributed by the differing degree of packing of the material. The void volume is much larger for oyster shell (Table 3). Thus, by weight, oyster shell provides much more surface area per MT than any limestone configuration (Table 3).

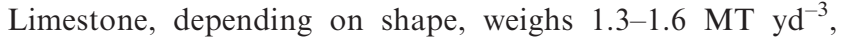
whereas the same volume of shell, contributing 1.35 times the exposed surface area, weighs just over half a metric ton. The much greater exposed surface area per oyster particle compensates for the lesser total amount of carbonate per cubic yard.

\section{Analyses of Field Samples}

Measurements were made of oyster shell and limestone particles from the Three Mile Bay site. The limestone had been planted. The oyster shell was natural, but would serve as the substrate mix that might be typical of remobilized reefal material. Analyses assumed that the particles analyzed are a relatively unbiased selection of the particles as they existed on the bottom. As most particles were analyzed, this is a reasonable assumption with the possible exception of oyster shell fragments, not all of which were sampled.

The vibracore samples processed at Three Mile Bay site consisted of only the small size class of limestone and comprised majorly the triangular prism and cuboidal shapes (Fig. 2). Two consecutive simulations were performed, one that only used limestone particles above $5 \mathrm{~cm}^{3}$ and one that included all limestone pieces (Table 4). The metrics for large $\left(\geq 5 \mathrm{~cm}^{3}\right)$ limestone particles are similar to those obtained from the industrial samples discussed in Section "Determination of Particle Total Surface Area and Exposed Surface Area." When the smaller particles are included, the resulting metrics show substantially more surface area for limestone owing to the larger surface area-to-volume ratio for smaller particles (Table 4). The expSA metric for the samples suggests that limestone outperformed shell in providing a maximum expSA per cubic yard of material and that the performance of limestone increased when all particles were included. Analysis of the industrial samples shows that the small-sized classes of limestone and triangular prism or cuboid shapes are the higher performing particle types.

The limestone plant at Three Mile Bay site demonstrates good performance metrics because it is composed of small limestone particles of the most preferred shapes. This allows for limestone to outperform whole oyster shell in this instance. It is, however, emphasized that smaller particles, by increasing the one-dimensionality of the plant, may in fact reduce performance in situ (Fig. 1). Information remains lacking as to the degree to which the assumption of a single exposed face for the larger particles is valid at different planting densities.

The metrics for whole oyster shell obtained from the Three Mile Bay site are similar to that observed for market-size oysters obtained from shucking houses (Table 4). This simulation 
TABLE 1.

The ratio of particle volume plus void volume to particle volume for shell and limestone particles.

\begin{tabular}{lc}
\hline \hline \multicolumn{1}{c}{ Particle type } & $\begin{array}{c}\text { Ratio (Particle Vol. }+ \\
\text { Void Vol. } \div \text { Particle Vol.) }\end{array}$ \\
\hline Whole market-size oyster shell & 5.39 \\
Limestone, square-base pyramid, \#57 & 2.69 \\
Limestone, triangular prism, \#4 & 2.11 \\
Limestone, cube, \#4 & 2.66 \\
Limestone, square-base pyramid, \#4 & 1.88 \\
Limestone, triangular-base pyramid, \#4 & 3.28 \\
Limestone, triangular-base pyramid, \#57 & 2.21 \\
Limestone, triangular prism, \#57 & 1.91 \\
Limestone, cube, \#57 & 1.99 \\
Oyster cultch (mostly fragments) & 1.69 \\
\hline
\end{tabular}

Particle types are defined in Table 1. The numbers 4 and 57 refer to size grades of limestone. Particles of grade 4 were compared with particles of grades 5-7 because these combinations have routinely been used in Louisiana cultch planting activities. Oyster cultch estimate is from HSRL (2012).

resulted in shell having slightly less exposed surface area than limestone. The shell component also had fragments as well as whole shells. Most of these would be considered minor fragments in the terminology of Davies et al. (1990). Fragments provided much more exposed surface area, by more than a factor of 6, than whole shells (Table 4) and outperform limestone of any composition and whole oyster shell alone by a large margin (Table 5). The degree to which oyster shell would provide more exposed surface area than the limestone composition planted at the Three Mile Bay site would depend largely on the mixture of whole shells and fragments planted (Table 5). Adding shell fragments, however, does increase the average weight of oyster shell per cubic yard appreciably.

\section{DISCUSSION}

Scarcity of oyster shell has led to the investigation of alternative materials for reef construction and recruitment enhancement (Nestlerode et al. 2007). Limestone has proven to be the most commonly used alternative. Limestone and shell perform relatively similarly in attracting oyster larvae to settle (Soniat et al. 1991, Anonymous 2004, Soniat \& Burton 2005). The selection of cultch material and planting density are

TABLE 2.

Parameter values for linear regressions between surface area and volume: surface area $=$ slope $\times$ volume + intercept.

\begin{tabular}{|c|c|c|c|c|}
\hline \multirow[b]{2}{*}{ Particle type } & \multicolumn{2}{|c|}{ Surface area } & \multicolumn{2}{|c|}{$\begin{array}{c}\text { Exposed } \\
\text { surface area }\end{array}$} \\
\hline & Intercept & Slope & Intercept & Slope \\
\hline Whole market-size oyster shell & 31.83 & 2.21 & 15.92 & 1.10 \\
\hline Limestone, square-base pyramid & 4.02 & 1.39 & 0.80 & 0.28 \\
\hline Limestone, cube & 11.43 & 2.62 & 1.90 & 0.44 \\
\hline Limestone, triangular-base pyramid & 3.40 & 1.63 & 1.32 & 0.46 \\
\hline Limestone, triangular prism & 6.59 & 2.32 & 0.85 & 0.41 \\
\hline
\end{tabular}

important decisions in any restoration or enhancement effort. Considerable interest has been given to the importance of surface complexity in providing surfaces for attachment or protective microhabitats that are not fully exposed to the overlying water (Gutiérrez et al. 2003, Kraeuter et al. 2003, Guay \& Himmelman 2004). The inside of empty oyster shells is a case in point (Butler 1955, Ritchie \& Menzel 1969, Powell et al. 2008). Oyster shell provides shelter from physical stresses and can provide a predation refuge (Gutierrez et al. 2003, Nestlerode et al. 2007). A true measure of available surface area on a natural reef has not been made; clearly, the degree of clumpiness of oysters, however, is important, as clumps are an important mechanism by which more than one surface of a shell remains exposed for recruitment and also clumps generate vertical complexity. Neither shell nor limestone plants can match this degree of surface exposure.

Unfortunately, few studies have been conducted to evaluate planting methods from the standpoint of maximizing surface exposure of the particles planted. Investigations have been made regarding the geographic area that a constructed reef spans in relation to the sustainability of the reef. Furlong (2012) warns against planting thin layers of cultch as they tend to be quickly dusted by sediment or subsumed, and thus do not provide surface area for recruitment as intended. Nevertheless, contrariwise, planting a thin layer may maximize surface area if sedimentation on the planting site is unlikely as might be the case in the use of planting to enhance recruitment on high quality oyster bottom. The tendency for planting on topographic highs (e.g., present reefs), or creating topography (created high-profile reefs-Lenihan 1999) as a mechanism to reduce sedimentation is a recognition that planted material tends to lie relatively flat on the bottom. A recent attempt to assess short- and long-term success of oyster reefs in the Gulf of Mexico emphasized that lack of detailed records of alternate planting options makes planning for further restoration difficult (La Peyre et al. 2014). In fact, very few observations of shell plants have been made to assess the on-bottom conditions for recruitment. Thus, best management practices are not available.

The calculation of exposed surface area is premised on the expectation that most shell plants will show a relatively planar aspect to the overlying water. As a consequence, only a portion of the total surface area will be exposed. In addition, observation of the Three Mile Bay plant suggests that limestone pieces, typically having four to six sides, pack sufficiently well that only one of these sides is likely to be exposed at normal planting densities. The following additional precautionary assumptions are made: (1) Shell is likely to rest concave up or concave down. This exposes one full valve side plus potentially some smaller portion of the other. It is assumed that only a single valve side is exposed. (2) It is assumed that no sediment cover compromises the surface area exposed. (3) It is assumed that particles of different sizes in the bulk material to be planted bring with them a proportional void volume based on the ratios shown in Figure 2. Thus, it is not considered that a small particle might wedge in between several larger ones, thereby displacing some of the void volume of the larger particles (Sanderson \& Donovan 1974). As the conversion factors came from measurements of the number of similarly shaped particles of a range of sizes that could be placed into a known volume of space (e.g., $\mathrm{yd}^{3}$ ), the ratios measured would have included the mixture of particle sizes that otherwise would have resulted from this tendency. Thus, large 
TABLE 3.

The surface area, exposed surface area, and weight of 1 cubic yard of the indicated particle type.

\begin{tabular}{|c|c|c|c|c|c|}
\hline Particle type & Size range & Surface area $\left(\mathrm{m}^{2} \mathrm{yd}^{-3}\right)$ & Exposed surface area $\left(\mathrm{m}^{2} \mathrm{yd}^{-3}\right)$ & Weight $\left(\right.$ MT $\left.\mathrm{yd}^{-3}\right)$ & Void volume $\left(\mathrm{yd}^{3}\right)$ \\
\hline Oyster shell & All & 85.2 & 42.6 & 0.57 & 0.81 \\
\hline Limestone & All & 163.1 & 32.0 & 1.36 & 0.58 \\
\hline Limestone & Grade $\# 5-7$ & 194.2 & 38.2 & 1.45 & 0.56 \\
\hline Limestone & Grade \#4 & 137.1 & 26.7 & 1.29 & 0.61 \\
\hline Limestone & All pyramidal & 111.0 & 24.9 & 1.27 & 0.61 \\
\hline Limestone & All prismatic & 211.5 & 42.3 & 1.63 & 0.50 \\
\hline Limestone & All cubic & 235.3 & 39.2 & 1.37 & 0.50 \\
\hline
\end{tabular}

The cubic yard included the volume of the particles themselves and the void volume. Limestone grades reflect sizes of the material, with grades 5-7 being smaller than grade \#4. "All" indicates a Monte Carlo simulation in which all measured particles of that type were included.

errors in the relationship of void space to particle volume would likely occur only if a small range of particle sizes were included in the known volume or if the mixture tested differed substantially from the mixture that provided the original void volume to particle volume ratios.

Whole oyster shell provides less total surface area, but owing to the concave shell shape and ability to create more complex structures, a higher associated void volume exists and also more exposed surface area. The mean weight of a cubic yard of whole shell per metric ton is significantly lower than any size or shape of limestone. Assuming equal costs by weight or volume, oyster shell outperforms any formation of limestone if purchases are to be made by weight. If purchased by volume, shell and limestone can perform similarly if the size and constituent shapes are favorable. Here, the important issue is the relative proportion of small to large limestone particles and the proportion of whole shells and fragments in the bulk compositions. More small limestone particles improve performance (i.e., provide more exposed surface area). More cubic and triangular prism-shaped limestone particles improve performance. More fragmented oyster shells improve performance. On the other hand, more small particles mean increased planarity, hence, less surficial complexity, and a greater susceptibility to sediment deposition. The relative importance of these processes in determining performance remains unknown.

What is known is that recruitment is a surface area phenomenon. For oysters, recruitment is in part a function of exposed surface area and a function of the fraction of exposed surface area that is "clean." Although considerable attention has been given to the settlement cues used by oyster larvae (Butler 1955, Hidu 1969, Hidu et al. 1978, Fitt \& Coon 1992), what the "clean" factor is remains poorly understood. Powell et al. (2009) suggested that the brood stock-recruitment relationship observed in Delaware Bay is, however, mostly a function of the tendency for the shells of live animals to be newer, cleaner, and have more exposed surface area than the remaining shell on the reef (see also Boudreaux et al. 2006). Shell planting is routinely successful if shell is planted at the time of spawning (Churchill 1920, Abbe 1988, Bushek et al. 2004, HSRL 2012). Typically planted shell recruits five times or more spat per bushel than does native shell. Analysis of time series data suggests that spat attach to live animal shells preferentially to other sources of native shell (Powell et al., 2008) and it is likely that planted shell and live shell have in common a clean surface appropriate for the fastidious oyster larva. Thus, in the first approximation, exposed clean surface area should be the determining performance metric.

The efficiency of material can be enhanced depending on the goal of a restoration effort. If the main goal of a project is to enhance recruitment, this study suggests that larger shell fragments are the best option to provide a maximum amount of exposed surface area per unit of purchased material. Limestone can provide an alternative that is approximately equal in performance if care is taken when selecting the size of the limestone particles and if the composition of shapes planted is favorable. As of yet, it is difficult to purchase a particular "shape" from an industrial source, which places a limit on the proficiency of limestone that would otherwise be provided. In addition, it is important to consider the characteristics of the environment into which the cultch is to be deposited. Limestone packing suggests that performance will decline faster than for oyster shell in areas prone to deposition of storm-resuspended sediment.

Oyster shell breaks down rapidly (Powell et al. 2006, Mann et al. 2009). Although the decay rate is not known, limestone is very likely to have a longer half life than oyster shell simply because oyster shell breaks down rapidly even in comparison with other bivalve shell and limestone's lower surface area to volume ratio provides added longevity as the rate of dissolution is proportional to surface area (Walter \& Morse 1984). Thus, limestone would appear to be a good candidate for reef expansion.

Louisiana Department of Wildlife and Fisheries compared \#57 limestone, \#57 concrete, and oyster shell as cultch in situ (Louisiana Department of Wildlife and Fisheries 2004). When the oyster shell was crushed to the same size as the limestone, a decrease in performance was measured; however, analysis was not standardized to the surface area. Thus, the report that oyster shell was less efficient than limestone or concrete could be attributed to differential settlement opportunity rather than settlement preference. We are unaware of any in situ comparison of material performance in enhancing recruitment that includes exposed surface area or even total surface area as the standardizing metric.

Powers et al. (2009) evaluated the performance of limestone and shell plants after a longer period and found limestone to perform inferiorly. Two caveats beyond the inferior performance reported by Powers et al. (2009) were offered. First, the planar aspect of limestone shell plants risks compromise by the smallest amount of depositing sediment. Thus, vertical relief is 
TABLE 4.

The surface area, exposed surface area, and weight of 1 cubic yard of the indicated particle type obtained from the Three Mile shell plant site.

\begin{tabular}{|c|c|c|c|c|}
\hline Particle type & Surface area $\left(\mathrm{m}^{2} \mathrm{yd}^{-3}\right)$ & Exposed surface area $\left(\mathrm{m}^{2} \mathrm{yd}^{-3}\right)$ & Weight (MT yd $^{-3}$ ) & Void volume $\left(\mathrm{m}^{2} \mathrm{yd}^{-3}\right)$ \\
\hline Whole oyster shell & 89.1 & 44.5 & 0.54 & 0.81 \\
\hline All oyster shell & 92.3 & 46.1 & 0.55 & 0.81 \\
\hline Oyster shell fragments & 630.8 & 315.5 & 2.01 & 0.41 \\
\hline Limestone $\geq 5 \mathrm{~cm}^{3}$ & 276.6 & 48.9 & 1.61 & 0.51 \\
\hline All limestone & 441.4 & 79.9 & 1.64 & 0.50 \\
\hline
\end{tabular}

The cubic yard included the volume of the particles themselves and the void volume. "All" indicates a Monte Carlo simulation in which all measured particles of that type were included.

likely an important element to success. Second, the packing density of limestone limits surface complexity and, therefore, likely limits the success of colonization and use by reef fauna typically dependent on the highly complex surface texture of the oyster reef (Grabowski \& Powers 2004, Coen et al. 2007, Summerhayes et al. 2009). Analysis of the limestone plant at Three Mile Bay confirms observations from cores that packing density for that plant was about one-third higher than those anticipated for whole oyster shell.

If the goal of a restoration project is to expand the footprint of a reef or increase its relief, then planting limestone as a base may be advantageous. Limestone is likely to be taphonomically resilient relative to oyster shell. We are unaware of any studies examining the rigidity of reef framework as a function of the subsurface carbonate content, a factor that is, however, likely to significantly influence the resiliency of reefs (Powell et al. 2012) because the structural integrity of the reef framework is critical to the resistance of the structure to storms and other waveinduced disturbances (Wall et al. 2005, Stiner \& Walters 2008).

The degree of packing of whole oyster shell is low. Although this is attractive from the standpoint of maximizing surface area for settlement of oyster larvae, it is unattractive from the standpoint of the construction of reef framework. Here, the attributes of limestone would be better. Oyster shells break down and produce fragments that comprise a significant portion of the cultch and much of the framework carbonate. Table 5 shows that increased fragmentation reduces the void volume of the reef framework that otherwise would be filled by terrigenous sediments and biodeposits. Increased contribution of framework volume by fragments is likely to be advantageous because increased packing should provide improved framework stability and reduce carbonate dissolution by reducing the amount of organic material incorporated within. Surficial shell will, however, ultimately be necessary to provide improved vertical complexity and increased surface area for recruitment.

This study has examined the potential relative performance of limestone and oyster shell based on an estimate of exposed surface area under certain constraining assumptions. The analysis of the Three Mile Bay limestone plant and associated oyster cultch shows that the proportion of small and large limestone particles and the relative proportion of whole shells and fragments can greatly alter the performance of materials. In this case, the a priori expectation that oyster shell would outperform limestone did not materialize because of the quantity of small limestone particles of favorable shapes in the deployed material. What is unclear is the degree to which small particles are functional as recruitment sites and the degree to which such particles fill voids and fail to contribute exposed surface area. Given the volume of carbonate planted yearly throughout much of the eastern oyster's range and the expense of this activity, the absence of information regarding performance in the field under a range of planting protocols, particle compositions, and desired outcomes is disturbing. Further research clearly is needed to provide better answers regarding performance in recruitment and taphonomic stability of cultch materials under alternative planting protocols and differentiating performance under framework and surficial habitat applications.

\section{ACKNOWLEDGMENTS}

Special thanks are due to Patrick Banks, Clarence Luquet, Chris Schieble, Diane Crouch, and Frank Wrangofski of the Louisiana Department of Wildlife and Fisheries for guidance

TABLE 5.

Examples of a mixture of whole oyster shell and fragments.

\begin{tabular}{|c|c|c|c|}
\hline Particle type & Surface area $\left(\mathrm{m}^{2} \mathrm{yd}^{-3}\right)$ & Weight (MT $\mathrm{yd}^{-3}$ ) & Void volume $\left(\mathrm{m}^{2} \mathrm{yd}^{-3}\right)$ \\
\hline Whole oyster shell + fragments & 92.3 & 0.55 & 0.81 \\
\hline Whole oyster shell $+10^{2}$ fragments & 125.8 & 0.87 & 0.73 \\
\hline Whole oyster shell $+10^{3}$ fragments & 236.6 & 1.71 & 0.53 \\
\hline Whole oyster shell $+10^{3}$ fragments (increased packing) & 312.3 & 2.27 & 0.37 \\
\hline
\end{tabular}

The top row provides the results from the measured shell material from the Three Mile cores. The subsequent rows assume additional fragments relative to whole shells in the planted material. The final row assumes that some fragments displace void volume contributed by whole shells by reducing the void (volume + particle volume):particle volume ratio from 1.69 to 1.11. A value of 1.11 was obtained from surf clam shell plants in Delaware Bay after the clam shell was broken into small fragments during processing at the clam shucking house (unpublished data, see also HSRL 2011). 
and field assistance in the Louisiana portion of the study. Mike Brown and Phil McCarty of the University of New Orleans collected core samples. Brad Robin supplied oyster shells; limestone was obtained from Pontchartrain Materials. This research was funded by the National Fish and Wildlife Foundation under a grant GR04702. We appreciate this support.

\section{LITERATURE CITED}

Abbe, G. R. 1988. Population structure of the American oyster, Crassostrea virginica, on an oyster bar in central Chesapeake Bay: changes associated with shell planting and increased recruitment. J. Shellfish Res. 7:33-40.

Agnello, R. J. \& L. P. Donnelley. 1975. Property rights and efficiency in the oyster industry. J. Law Econ. 18:521-533.

Anonymous. 2004. Final report for Louisiana's oyster shell recovery pilot project. Louisiana Department of Wildlife \& Fisheries, NOAA Award NA96FK0188.

Beck, M. W., R. D. Brumbaugh, L. Airoldi, A. Carranza, L. D. Coen, C. Crawford, O. Defeo, G. J. Edgar, B. Hancock, M. Kay, H. Lenihan, M. W. Luckenbach, C. L. Toropova \& G. Zhang. 2009. Shellfish reefs at risk a global analysis of problems and solutions. Arlington, VA: The Nature Conservancy. 52 pp.

Boudreaux, M. L., J. L. Stiner \& L. J. Walters. 2006. Biodiversity of sessile and motile macrofauna on intertidal oyster reefs in Mosquito Lagoon, Florida. J. Shellfish Res. 25:1079-1089.

Breitburg, D. L., L. D. Coen, M. W. Luckenbach, R. Mann, M. Posey \& J. A. Wesson. 2000. Oyster reef restoration: convergence of harvest and conservation strategies. J. Shellfish Res. 19:371-377.

Bushek, D., D. Richardson, M. Y. Bobo \& L. D. Coen. 2004. Quarantine of oyster shell cultch reduces the abundance of Perkinsus marinus. J. Shellfish Res. 23:369-373.

Butler, P. A. 1955. Selective setting of oyster larvae on artificial cultch. Proc. Natl. Shellfish. Assoc. 45:95-105.

Churchill, E. P., Jr. 1920. The oyster and oyster industry of the Atlantic and Gulf coasts. Bureau of Fisheries Document no. 890. Washington, DC: Government Printing Office. 51 pp.

Coen, L. D., R. D. Brumbaugh, D. Bushek, R. Grizzle, M. W. Luckenbach, M. H. Posey, S. P. Powers \& S. E. Tolley. 2007. Ecosystem services related to oyster restoration. Mar. Ecol. Prog. Ser. 341:303-307.

Davies, D. J., G. M. Staff, W. R. Callender \& E. N. Powell. 1990. Description of a quantitative approach to taphonomy and taphofacies analysis: all dead things are not created equal. In: W. Miller III, editor. Paleocommunity temporal dynamics: the long-term development of multispecies assemblages. Boulder, CO: Special Publication (Paleontological Society) 5. pp. 328-350.

DeAlteris, J. T. 1988. The geomorphic development of Wreck Shoal, a subtidal oyster reef of the James River, Virginia. Estuaries 11:240-249

Fitt, W. K. \& S. L. Coon. 1992. Evidence for ammonia as a natural cue for recruitment of oyster larvae to oyster beds in a Georgia salt marsh. Biol. Bull. 182:401-408.

Furlong, J. N. 2012. Artificial oyster reefs in the northern Gulf of Mexico: management, materials, and faunal effects. MS Thesis, Louisiana State University Electronic Thesis and Dissertation Collection ETD-06132012-224706.

Grabowski, J. H. \& S. P. Powers. 2004. Habitat complexity mitigates trophic transfer on oyster reefs. Mar. Ecol. Prog. Ser. 277:291-295.

Gregalis, K. C., M. W. Johnson \& S. P. Powers. 2009. Restored oyster reef location and design affect responses of resident and transient fish, crab, and shellfish species in Mobile Bay, Alabama. Trans. Am. Fish. Soc. 138:314-327.

Gregalis, K. C., S. P. Powers \& K. L. Heck, Jr. 2008. Restoration of oyster reefs along a bio-physical gradient in Mobile Bay, Alabama. J. Shellfish Res. 27:1163-1169.

Guay, M. \& J. H. Himmelman. 2004. Would adding scallop shells (Chlamys islandica) to the sea bottom enhance recruitment of commercial species? J. Exp. Mar. Biol. Ecol. 312:299-317.
Gunter, G. 1972. Use of dead reef shell and its relation to estuarine conservation. Trans. N. Am. Wildl. Nat. Res. Conf. pp. 110-121.

Gunter, G. 1979. The grit principle and the morphology of oyster reefs. Proc. Natl. Shellfish. Assoc. 69:1-5.

Gutiérrez, J. L., C. G. Jones, D. L. Strayer \& O. O. Iribarne. 2003. Mollusks as ecosystem engineers: the role of shell production in aquatic habitats. Oikos 101:79-90.

Harding, J. M., R. Mann, M. J. Southworth \& J. A. Wesson. 2010. Management of the Piankatank River, Virginia, in support of oyster (Crassostrea virginica, Gmelin 1791) fishery repletion. J. Shellfish Res. 29:867-888.

Hargis, W. J., Jr. \& D. S. Haven. 1994. The precarious state of the Chesapeake public oyster resource. In: P. Hill \& S. Nelson, editors. Toward a sustainable coastal watershed: the Chesapeake experiment. Proceedings of the conference, June 1-3, 1994, Norfolk, VA, Ches. Res. Consortium Publ. 149, pp. 559-584.

Haven, D. S., J. M. Zeigler, J. T. DeAlteris \& J. P. Whitcomb. 1987. Comparative attachment, growth and mortalities of oyster (Crassostrea virginica) spat on slate and oyster shell in the James River, Virginia. J. Shellfish Res. 6:45-48.

Hedgpeth, J. W. 1953. An introduction to the zoogeography of the northwestern Gulf of Mexico with reference to the invertebrate fauna. Publ. Inst. Mar. Sci. 3:207-224.

Hidu, H. 1969. Gregarious setting in the American oyster Crassostrea virginica Gmelin. Chesap. Sci. 10:85-92.

Hidu, H., W. G. Valleau \& F. P. Veitch. 1978. Gregarious setting in European and American oysters-response to surface chemistry vs. waterborne pheromones. Proc. Natl. Shellfish. Assoc. 68:1116.

Hopkins, S. H. 1950 The inter-relationship of weight, volume, and linear measurements of oysters and the number of oysters per Louisiana sack measure. College Station, TX: Texas A\&M Research Foundation Report, Project 9, 7 pp.

HSRL. 2011. Report of the 2011 Stock Assessment Workshop (13 ${ }^{\text {th }}$ SAW) for the New Jersey Delaware Bay Oyster Beds. Haskin Shellfish Research Laboratory, Rutgers University, Port Norris, NJ. 155 pp.

HSRL. 2012. Report of the 2012 Stock Assessment Workshop (14 ${ }^{\text {th }}$ SAW) for the New Jersey Delaware Bay Oyster Beds. Haskin Shellfish Research Laboratory, Rutgers University, Port Norris, NJ. 168 pp.

Jordan, S. J. \& J. M. Coakley. 2004. Long-term projections of eastern oyster populations under various management scenarios. J. Shellfish Res. 23:63-72.

Kennedy, V. S., D. L. Breitburg, M. C. Christman, M. W. Luckenbach, K. Paynter, J. Kramer, K. G. Sellmer, J. Dew-Baxter, C. Keller \& R. Mann. 2011. Lessons learned from efforts to restore oyster populations in Maryland and Virginia, 1990 to 2007. J. Shellfish Res. 30:719-731.

Kingsley-Smith, P. R., R. E. Joyce, S. A. Arnott, W. A. Roumillat, C. J. McDonough \& M. J. M. Reichert. 2012. Habitat use of intertidal eastern oyster (Crassostrea virginica) reefs by nekton in South Carolina estuaries. J. Shellfish Res. 31:1009-1021.

Kraeuter, J. N., M. J. Kennish, J. Dobarro, S. R. Fegley \& G. E. Flimlin, Jr. 2003. Rehabilitation of the northern quahog (hard clam) (Mercenaria mercenaria) habitat by shelling-11 years in Barnegat Bay, New Jersey. J. Shellfish Res. 22:61-67.

La Peyre, M., J. Furlong, L. A. Brown, B. P. Piazza \& K. Brown. 2014. Oyster reef restoration in the northern Gulf of Mexico: extent, methods and outcomes. Ocean Coast. Manage. 89:20-28. 
Lenihan, H. S. 1999. Physical-biological coupling on oyster reefs: how habitat structure influences individual performance. Ecol. Monogr. 69:251-275.

Lenihan, H. S. \& C. H. Peterson. 1998. How habitat degradation through fishery disturbance enhances impacts of hypoxia on oyster reefs. Ecol. Appl. 8:128-140.

Lipton, D. 2008. Economic benefits of a restored oyster fishery in Chesapeake Bay. J. Shellfish Res. 27:619-623.

Louisiana Department of Wildlife and Fisheries. 2004. Louisiana's oyster shell recovery pilot project. Final Report of NOAA Award No. NA96FK0188, Socioeconomics Research and Development Section and Marine Fisheries Division. 253 pp.

Lunz, G. R. 1957. Unused oyster shell in South Carolina suitable for seed oyster production. Proc. Natl. Shellfish. Assoc. 48:44-51.

Mackenzie, C. L., Jr. 1996. History of oystering in the United States and Canada, featuring the eight greatest oyster estuaries. Mar. Fish. Rev. 58:1-78.

Mackenzie, C. L., Jr. 2007. Causes underlying the historical decline in eastern oyster (Crassostrea virginica Gmelin, 1791) landings. J. Shellfish Res. 26:927-938.

Mann, R., E. M. Burreson \& P. K. Baker. 1991. The decline of the Virginia oyster fishery in Chesapeake Bay: considerations for the introduction of a non-endemic species, Crassostrea gigas (Thunberg, 1793). J. Shellfish Res. 10:379-388.

Mann, R., J. M. Harding \& M. J. Southworth. 2009. Reconstructing pre-colonial oyster demographics in the Chesapeake Bay, USA. Estuar. Coast. Shelf Sci. 85:217-222.

Mann, R. \& E. N. Powell. 2007. Why oyster restoration goals in the Chesapeake Bay are not and probably cannot be achieved. J. Shellfish Res. 26:905-917.

Mississippi Department of Environmental Quality (MDEQ). 2013. \$11 million oyster reef restoration. Restorems. Accessed March 24, 2014. Available at: http://www.restore.ms/2013/05/21/11-millionoyster-reef-restoration/.

Nestlerode, J. A., M. W. Luckenbach \& F. X. O'Beirn. 2007. Settlement and survival of the oyster Crassostrea virginica on created oyster reef habitats in Chesapeake Bay. Restor. Ecol. 15:273-283.

Owen, H. M. 1953. Growth and mortality of oysters in Louisiana. Bull. Mar. Sci. Gulf Caribb. 3:44-54.

Parsons-Hubbard, K. M., W. R. Callender, E. N. Powell, C. E. Brett, S. E. Walker, A. L. Raymond \& G. M. Staff. 1999. Rates of burial and disturbance of experimentally-deployed molluscs: implications for preservation potential. Palaios 14:337-351.

Peterson, C. H., J. H. Grabowski \& S. P. Powers. 2003. Estimated enhancement of fish production resulting from restoring oyster reef habitat: quantitative valuation. Mar. Ecol. Prog. Ser. 264:249-264.

Powell, E. N., K. A. Ashton-Alcox, J. N. Kraeuter, S. E. Ford \& D. Bushek. 2008. Long-term trends in oyster population dynamics in Delaware Bay: regime shifts and response to disease. J. Shellfish Res. 27:729-755.

Powell, E. N., J. M. Klinck, K. Ashton-Alcox, E. E. Hofmann \& J. M. Morson. 2012. The rise and fall of Crassostrea virginica oyster reefs: the role of disease and fishing in their demise and a vignette on their management. J. Mar. Res. 70:505-558.

Powell, E. N., J. M. Klinck, K. A. Ashton-Alcox \& J. N. Kraeuter. 2009. Multiple stable reference points in oyster populations: biological relationships for the eastern oyster (Crassostrea virginica) in Delaware Bay. Fish Bull. 107:109-132.

Powell, E. N., J. N. Kraeuter \& K. A. Ashton-Alcox. 2006. How long does oyster shell last on an oyster reef? Estuar. Coast. Shelf Sci. 69:531-542.

Powers, S. P., C. H. Peterson, J. H. Grabowski \& H. S. Lenihan. 2009. Success of constructed oyster reefs in no-harvest sanctuaries: implications for restoration. Mar. Ecol. Prog. Ser. 389:159-170.
Ritchie, T. P. \& R. W. Menzel. 1969. Influence of light on larval settlement of American oysters. Proc. Natl. Shellfish. Assoc. 59:116-120.

Rothschild, B. J., J. S. Ault, P. Goulletquer \& M. Héral. 1994. Decline of the Chesapeake Bay oyster populations: a century of habitat destruction and overfishing. Mar. Ecol. Prog. Ser. 111:29-39.

Sammarco, P. W., S. R. Kolian, R. A. F. Warby, J. L. Bouldin, W. A. Subra \& S. A. Porter. 2013. Distribution and concentrations of petroleum hydrocarbons associated with the BP/Deepwater Horizon oil spill, Gulf of Mexico. Mar. Pollut. Bull. 73:129-143.

Sanderson, D. J. \& R. N. Donovan. 1974. The vertical packing of shells and stones on some recent beaches. J. Sediment. Petrol. 44:680-688.

Santopietro, G. D., K. Stephenson, V. A. Satyal \& J. Wesson. 2009. A bioeconomic analysis of management plans for the public oyster ground of the Rappahannock River. J. Shellfish Res. 28:235-241.

Soniat, T. M., B. C. Broadhurst, III \& E. L. Haywood, III. 1991. Alternatives to clam shell as cultch for oysters and the use of gypsum for the production of cultchless oysters. J. Shellfish Res. 10:405-410.

Soniat, T. M. \& G. M. Burton. 2005. A comparison of the effectiveness of sandstone and limestone as cultch for oysters, Crassostrea virginica. J. Shellfish Res. 24:483-485.

Soniat, T. M., N. Cooper, E. N. Powell, J. M. Klinck, M. Abdelguerfi, S. Tu, \& R. Mann \& P. D. Banks 2014. Estimating sustainable harvests of eastern oysters, Crassostrea virginica. J. Shellfish Res. 33:381-394.

Soniat, T. M., J. M. Klinck, E. N. Powell, N. Cooper, M. Abdelguerfi, E. E. Hofmann, J. Dahal, S. Tu, J. Finigan, B. S. Eberline, J. F. La Peyre, M. K. La Peyre \& F. Qaddoura. 2012. A shellneutral modeling approach yields sustainable oyster harvest estimates: a retrospective analysis of the Louisiana State primary seed grounds. J. Shellfish Res. 31:1103-1112.

Southworth, M., J. M. Harding, J. A. Wesson \& R. Mann. 2010. Oyster (Crassostrea virginica, Gmelin 1791) population dynamics on public reefs in the Great Wicomico River, Virginia, USA. J. Shellfish Res. 29:271-290.

Stiner, J. L. \& L. J. Walters. 2008. Effects of recreational boating on oyster reef architecture and species interactions. Fla. Sci. 71:31-44.

Summerhayes, S. A., M. J. Bishop, A. Leigh \& B. P. Kelaher. 2009. Effects of oyster death and shell disarticulation on associated communities of epibiota. J. Exp. Mar. Biol. Ecol. 379:60-67.

Toline, C. A., P. Kenny \& D. Bushek. 2005. Cement-coated stakes enhance recruitment of damaged oyster reefs (South Carolina). Ecol. Res. 23:277-278.

Vanderkooy, S. J. (Ed.). 2011. The oyster fishery of the Gulf of Mexico, United States a fisheries management plan. 2011 Revision. Ocean Springs, MS: Gulf States Marine Fisheries Commission.

Wall, L. M., L. J. Walters, R. E. Grizzle \& P. E. Sacks. 2005. Recreational boating activity and its impact on the recruitment and survival of the oyster Crassostrea virginica on intertidal reefs in Mosquito Lagoon, Florida. J. Shellfish Res. 24:965-973.

Walter, L. M. \& J. W. Morse. 1984. Reactive surface area of skeletal carbonates during dissolution: effect of grain size. J. Sediment. Petrol. 54:1081-1090.

Weiner, R. M., A. M. Segall \& R. R. Colwell. 1985. Characterization of a marine bacterium associated with Crassostrea virginica (the eastern oyster). Appl. Environ. Microbiol. 49:83-90.

Wirth, F. F. \& T. M. Minton. 2004. A review of the market structure of the Louisiana oyster industry: a microcosm of the United States oyster industry. J. Shellfish Res. 23:841-847.

Woods, H., W. J. Hargis, Jr., C. H. Hershner \& P. Mason. 2005. Disappearance of the natural emergent 3-dimensional oyster reef system of the James River, Virginia, 1871-1948. J. Shellfish Res. 24:139-142. 